\title{
Hidden Middle Devonian Magmatism of North-Eastern Siberia: Age Constraints from Detrital Zircon U-Pb Data
}

\author{
Victoria B. Ershova ${ }^{1,2,3, * \mathbb{C} \text {, Andrei V. Prokopiev }}{ }^{3}$ and Andrei K. Khudoley ${ }^{1}$ \\ 1 Institute of Earth Sciences, St. Petersburg State University, Universitetskaya nab. 7/9, 199034 St. Petersburg, \\ Russia; a.khudoley@spbu.ru \\ 2 Geological Institute, Russian Academy of Sciences, 109017 Moscow, Russia \\ 3 Diamond and Precious Metal Geology Institute, Siberian Branch, Russian Academy of Sciences, Lenin Av. 39, \\ 677980 Yakutsk, Russia; prokopiev@diamond.ysn.ru \\ * Correspondence: v.ershova@spbu.ru
}

Received: 24 August 2020; Accepted: 26 September 2020; Published: 1 October 2020

\begin{abstract}
We present new data on the tectonic evolution of north-eastern Siberia using an integrated provenance analysis based on $\mathrm{U}-\mathrm{Pb}$ detrital zircon dating and sandstone petrography of Devonian sedimentary strata. Our petrographic data suggest that Upper Devonian sandstones of north-eastern Siberia were derived from a local provenance, supported by the widespread distribution of ca. 1900-2000 Ma magmatic events in the basement of the neighboring Ust'-Lena and Olenek uplifts. Devonian detrital zircon age distributions of the Devonian sandstones are similar to ages of Middle Paleozoic magmatic rocks of Yakutsk-Vilyui large igneous province (LIP). Therefore, we suggest that the studied sandstones were derived from proximally-located uplifted blocks composed of Proterozoic-Devonian rocks and Middle-Late Devonian volcanics. Moreover, the abundance of Middle-Late Devonian zircons is suggestive of a wider distribution of coeval magmatism across north-eastern Siberia than previously supposed. We propose that widespread Devonian magmatism associated with the Yakutsk-Vilyui LIP also occurred to the east of our study area and is now buried beneath thick Carboniferous-Jurassic sedimentary rocks of the eastern Siberian passive margin, subsequently deformed into the Late Jurassic-Cretaceous Verkhoyansk fold-and-thrust belt. We also propose that the major pulse of the Yakutsk-Vilyui LIP occurred in north-eastern Siberia during the Middle Devonian at ca. $390 \mathrm{Ma}$, some 15 million years earlier than within the Vilyui rift basin in eastern Siberia (ca. $375 \mathrm{Ma}$ ).
\end{abstract}

Keywords: Siberia; Arctic; Middle Paleozoic; paleogeography; detrital zircons

\section{Introduction}

The numerous detrital zircon $\mathrm{U}-\mathrm{Pb}$ studies provide important constraints on the paleogeography and tectonics of sedimentary basins and their surrounding landmasses. Numerous $\mathrm{U}-\mathrm{Pb}$ detrital zircon studies have been carried out on the sedimentary strata of northern Siberia from both the Precambrian [1-3] and Carboniferous-Mesozoic succession [4-8]. However, detrital zircon U-Pb provenance studies have not been previously conducted on the Devonian strata of northern Siberia.

The Devonian Period was characterized by significant tectonic and magmatic events across south-eastern Siberia, which resulted in formation of the Yakutsk-Vilyui large igneous province (LIP) ([9-13] and references therein). The Yakutsk-Vilyui LIP is a giant radiating mafic dyke swarm and rift basins, converging on an assumed mantle plume center along the eastern margin of the Siberian Craton [11-16]. Coeval carbonatites and kimberlites are associated with the Yakutsk-Vilyui LIP of eastern Siberia, with the Vilyui rift/Vilyui basin representing the main rift basin associated with the LIP across the eastern part of the Siberian Craton [9]. The Yakutsk-Vilyui LIP is one of the largest 
LIP of the Phanerozoic, exerting a major impact on the tectonic evolution of Siberia and surrounding landmasses and furthermore, possibly exerted a significant global impact on the biota and climate of the Middle-Late Devonian [10].

Therefore, understanding the Middle-Late Devonian tectonic evolution of Siberia is important at both regional and global scales. This paper presents a new integrated provenance study based on the petrography and $\mathrm{U}-\mathrm{Pb}$ detrital zircon dating of Devonian sandstones deposited along the north-eastern margin of the Siberian Craton (present day coordinates) (Figure 1). Our study helps to refine the nature and location of sediment provenance regions, providing implications for the tectonic setting of Devonian clastic rocks along with the surrounding landmasses.

\section{Geological Setting}

The study region is located along the boundary between the Middle Paleozoic-Mesozoic passive eastern margin of the Siberian Craton and Mesozoic Verkhoyansk fold-and-thrust belt (Figure 1). The Siberian Craton represents the north-eastern part of the Eurasian Plate and is bounded by fold belts of various ages.

The basement of the Siberian Craton comprises Archean and early Paleoproterozoic terranes. These terranes were mainly amalgamated to form the Siberian Craton between 2000 and $1900 \mathrm{Ma}$ [17,18]. The basement rocks crop out on the Anabar Shield and the Olenek and Ust'-Lena uplifts across north-eastern Siberia $[17,19]$ (Figure 1). It is assumed that the Ust'-Lena uplift locates in tectonic sheet of the front of the Verkhoyansk fold-and-thrust belt (Kharaulakh anticlinorium) and represents the northernmost part of Siberia basement [19].

The oldest sedimentary strata overlie Siberian basement with a significant gap and are Meso-Neoproterozoic in age. The Meso-Neoproterozoic strata comprise mainly clastic rocks, although some thick carbonate units are also known $[1,20]$. The total thickness of the Meso-Neoproterozoic succession reaches $2000 \mathrm{~m}$. The Ediacaran part of the succession comprises mainly clastic rocks at the base but transitions upward to predominantly carbonate rocks, attaining a thickness of $400 \mathrm{~m}$ across the study area. Ediacaran rocks unconformably overlie various older Meso-Neoproterozoic sedimentary deposits across north-eastern Siberia, as well as Archean-Paleoproterozoic basement on the Olenek Uplift and Anabar Shield. The Cambrian successions of northern and north-eastern Siberia comprise predominantly carbonate rocks, reaching a thickness of 600-750 $\mathrm{m}[1,20]$. Ordovician and Silurian strata have a patchy distribution across the study area. The most complete section was penetrated by a borehole near the mouth of the Olenek River and comprises dark grey and black clayey limestones with thickness reaches up to several hundred meters of [21]. The Ediacaran-Silurian carbonates are overlain by a thick succession of Carboniferous-Lower Cretaceous clastic rocks, deposited along the north-eastern passive margin of the Siberian Craton. Small outcrops of Devonian strata occur across northern Siberia (southern Taimyr Peninsula and Anabar Bay), where they comprise predominantly carbonates with subordinate clastic and evaporite units [22-24].

The Verkhoyansk fold-and-thrust belt formed in the Late Jurassic-Cretaceous as a result of collision between the Siberian Craton and Kolyma-Omolon Superterrane [25]. The deformed Ediacaran-Paleozoic passive margin of Siberia is exposed within the Kharaulakh anticlinorium. The Kharaulakh anticlinorium mainly comprises Permian strata which unconformably overlie Cambrian carbonates, with Carboniferous and Devonian strata only preserved in its north-western part.

Cambrian strata comprise a $1000 \mathrm{~m}$ thick carbonate succession, with latest Ediacaran-earliest Cambrian rhyolites and basalts reported from north-eastern Siberia [2,26,27]. Devonian deposits crop out in a few localities and mainly consist of interbedded carbonates, calcarenites, and litharenites, with subordinate shale beds. A $>400 \mathrm{~m}$ thick unit comprising basalt flows has also been described from the northernmost part of the anticlinorium (along the Bykov channel of the Lena Delta) [20,28]. Carboniferous and Permian rocks comprise sandstones, siltstones and argillites, attaining a thickness of up to several kilometers. 

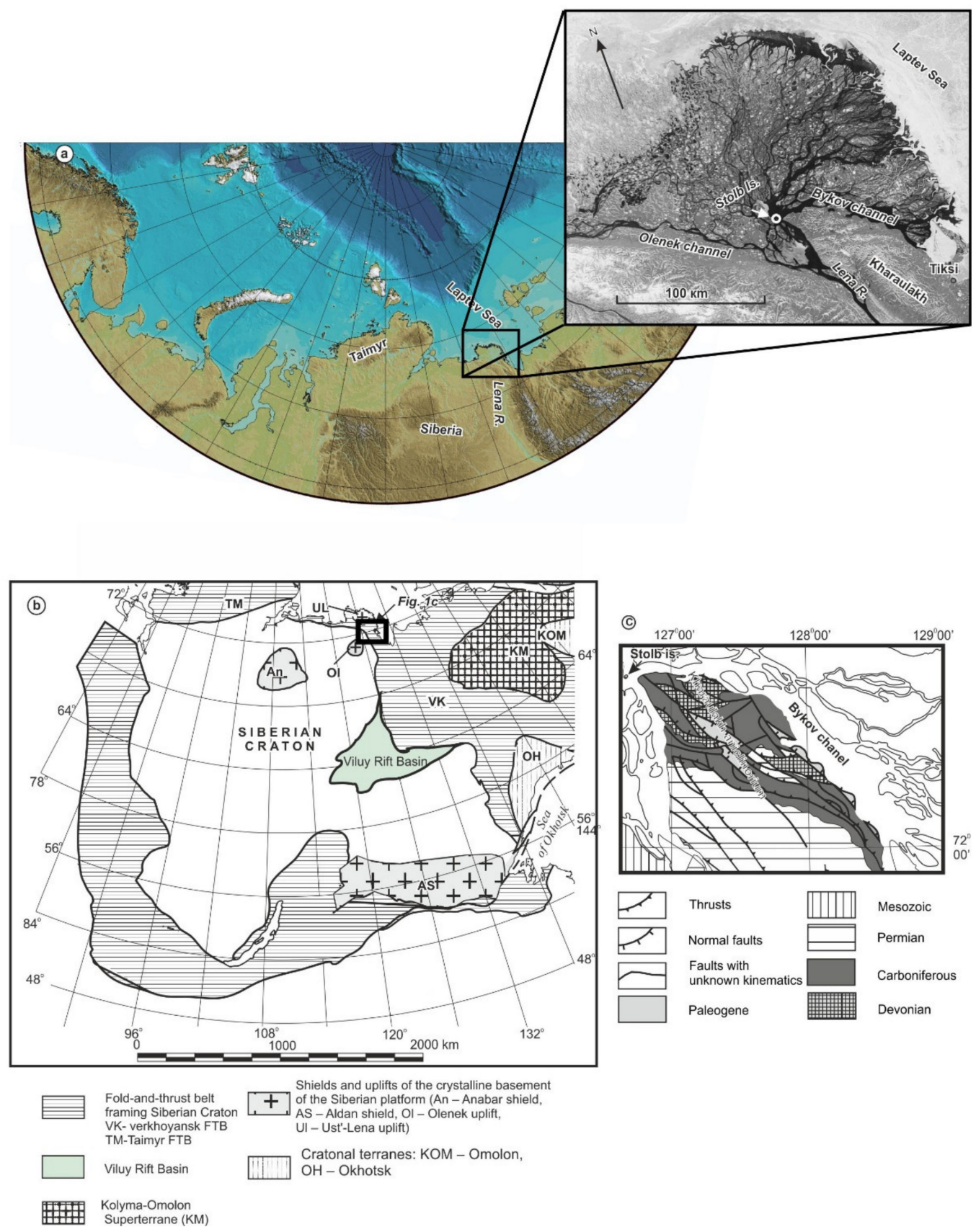

Figure 1. (a) Location map of the study area; (b) Simplified map of the Siberian Craton and surrounding orogenic belts (modified from [29,30]); (c) Simplified geological map of the study area.

Ordovician and Silurian rocks have also been described from a small fault-bounded unit in the northernmost part of the Kharaulakh anticlinorium [25].

The Devonian deposits, which are the main focus of this paper, are discussed here in detail. Lower Devonian strata have not been reported from north-eastern Siberia but Middle to Upper Devonian rocks are known at several locations in the northern part of the Verkhoyansk fold-and-thrust belt (western part of the Kharaulakh anticlinorium) and in the Lena River Delta area [20,24,31-33]. Middle Devonian (Givetian) rocks have been recorded within a single tectonic block in the northern part of the Verkhoyansk fold-and-thrust belt (Kharaulakh anticlinorium). They comprise $200 \mathrm{~m}$ of limestone and dolomitized limestone [25]. The Middle Devonian age of these strata is based on coral and brachiopod biostratigraphy [34]. Frasnian deposits mainly consist of limestones, dolomitized limestones 
and sandstones, with up to 300 m-thick basalt flows within the middle part of the succession [35]. The limestone is characterized by diverse assemblages of bivalves, pteropods brachiopods, and corals. The Famennian deposits comprise up to $400 \mathrm{~m}$ thick succession of intercalating calcareous sandstone and siltstone with subordinate limestone and marl [24,33,34] (Figure 2).
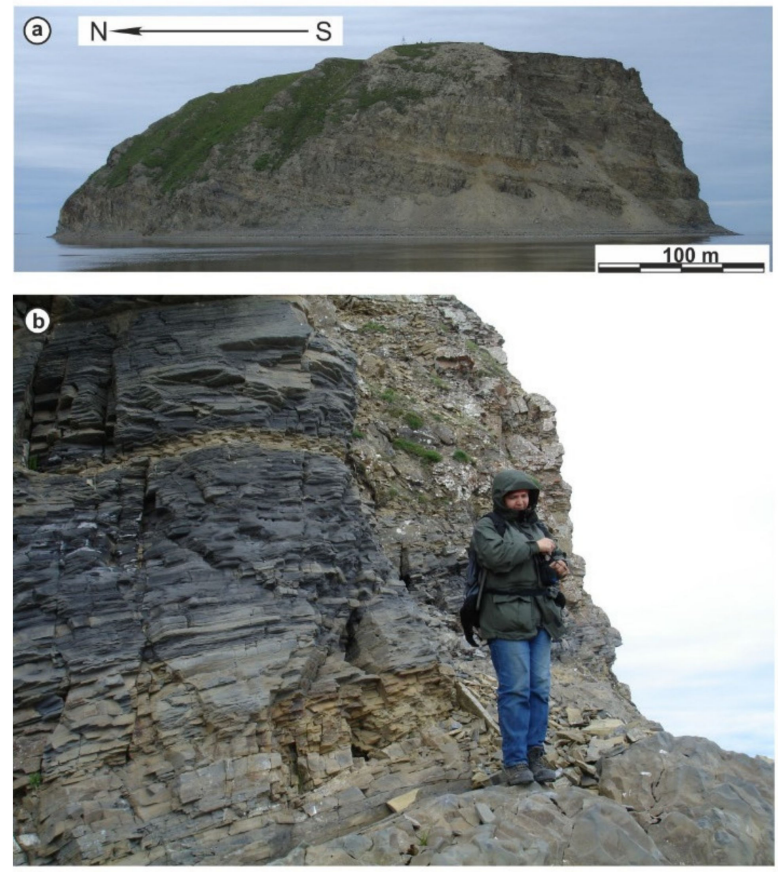

(C)

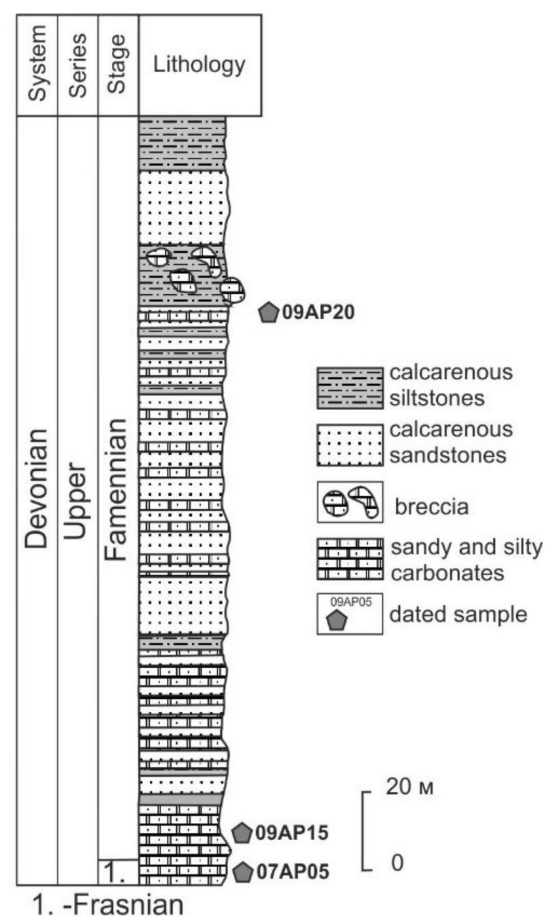

Figure 2. (a) General view of Stolb Island; (b) Close up view of studied section; (c) Simplified stratigraphic column of the Devonian strata of Stolb Island with positions of dated samples, Lena Delta area (modified from [32]).

\section{Analytical Methodology}

Samples were crushed and the heavy minerals concentrated using standard techniques at the Institute of Precambrian Geology and Geochronology, Russian Academy of Science. The zircon grains were mounted in epoxy and polished.

$\mathrm{U}-\mathrm{Pb}$ age data were obtained at the Geological Survey of Denmark and Greenland, Copenhagen, through laser ablation-single collector-magnetic sector-field-inductively coupled plasma-mass spectrometry (LA-SF-ICP-MS), employing a Thermo-Fisher Element 2 mass spectrometer (Thermo Fisher Scientific, Waltham, MA, USA) coupled to a New Wave UP213 laser ablation system (Elemental Scientific Lasers, Bozeman, MT, USA). Data were acquired by single spot analyses using a frequency of $10 \mathrm{~Hz}, 3-10 \mathrm{~J} / \mathrm{cm}^{2}$ and a spot diameter of 25 or $30 \mu \mathrm{m}$, producing a crater depth of ca. 20-25 $\mu \mathrm{m}$. The methods employed for analysis and data processing are described in detail by [35,36]. For quality control, the Plešovice [37] and M127 [38] zircon reference standards were analyzed during the sequence, yielding consistent results with published ID-TIMS (isotope dilution thermal ionization mass spectrometry) ages. $206 \mathrm{~Pb} / 238 \mathrm{U}$ ages are reported for zircons younger than $1000 \mathrm{Ma}$ and $207 \mathrm{~Pb} / 206 \mathrm{~Pb}$ ages for older zircons. Following [39], only analyses with a discordance of $<30 \%$ were used for the following interpretations. Data tables are presented in Supplementary S1. The histogram was constructed using the detzrcr software (University of Oslo, Oslo, Norway). [40]. 


\section{Results}

\subsection{Petrography of Studied Rocks}

The Devonian sandstones are classified as poorly sorted arkosic arenites, subarkoses, and sublitharenites (Figure 3). Quartz grains are the most abundant constituent and comprising 60-75\% of the population. Monocrystalline quartz predominates but small numbers of polycrystalline quartz grains also occur. Feldspar contributes $20-30 \%$ of the framework grains. Quartz and feldspar grains have a sub-rounded to sub-angular shape. Lithic grains (10-30\%) mainly comprise rounded to sub-angular sedimentary and volcanic rocks (mainly basalts). Carbonate lithic fragments constitute 90-95\% of the total lithic grains, whilst shale clasts are rare. Volcanic rocks and schist are subordinate.
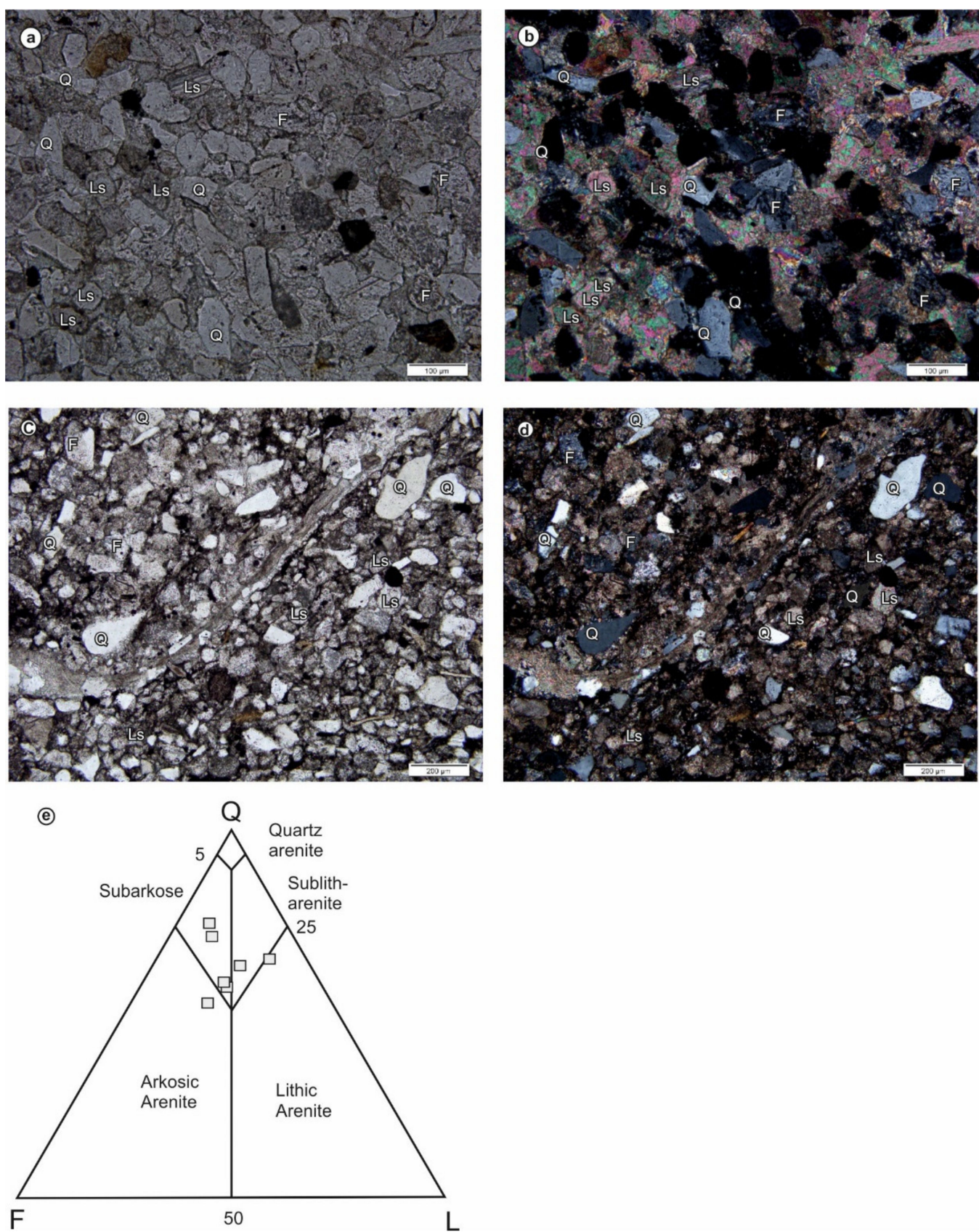

Figure 3. Sandstone petrography. (a-d) Subarkose from the studied section; Q-quartz; F-feldspar, Ls—lithic sedimentary grains, Lv—lithic volcanic grains. (e) QFL diagrams after [41]; Q-quartz; F-feldspar, L-lithic fragments. For each sample, more than 300 grains were counted and categorized. 


\subsection{U-Pb Dating of Detrital Zircons}

The three dated samples were collected from Frasnian-Famennian strata exposed on Stolb Island in the Lena River Delta. Frasnian deposits exposed on Stolb Island comprise $7 \mathrm{~m}$ of calcareous sandstone (Figure 2), dolomite, limestone, and marl, while Famennian deposits comprise $190 \mathrm{~m}$ of interbedded calcareous sandstone, siltstone, dolostone, limestone, and subordinate marls and shales.

\section{Sample 07AP05 (Frasnian)}

Seventy percent of analyzed grains are Precambrian in age, with Archean grains ranging in age from 2515 to $2609 \mathrm{Ma}$ and forming a minor peak at $2550 \mathrm{Ma}$ (Figure 4). Paleoproterozoic grains comprise $48 \%$ of the total population and form peaks at 2000 and $1850 \mathrm{Ma}$. Neoproterozoic zircons $(15 \%)$ do not form a prominent peak. Paleozoic grains (30\%) are represented entirely by Devonian ages and group at ca. $390 \mathrm{Ma}$.
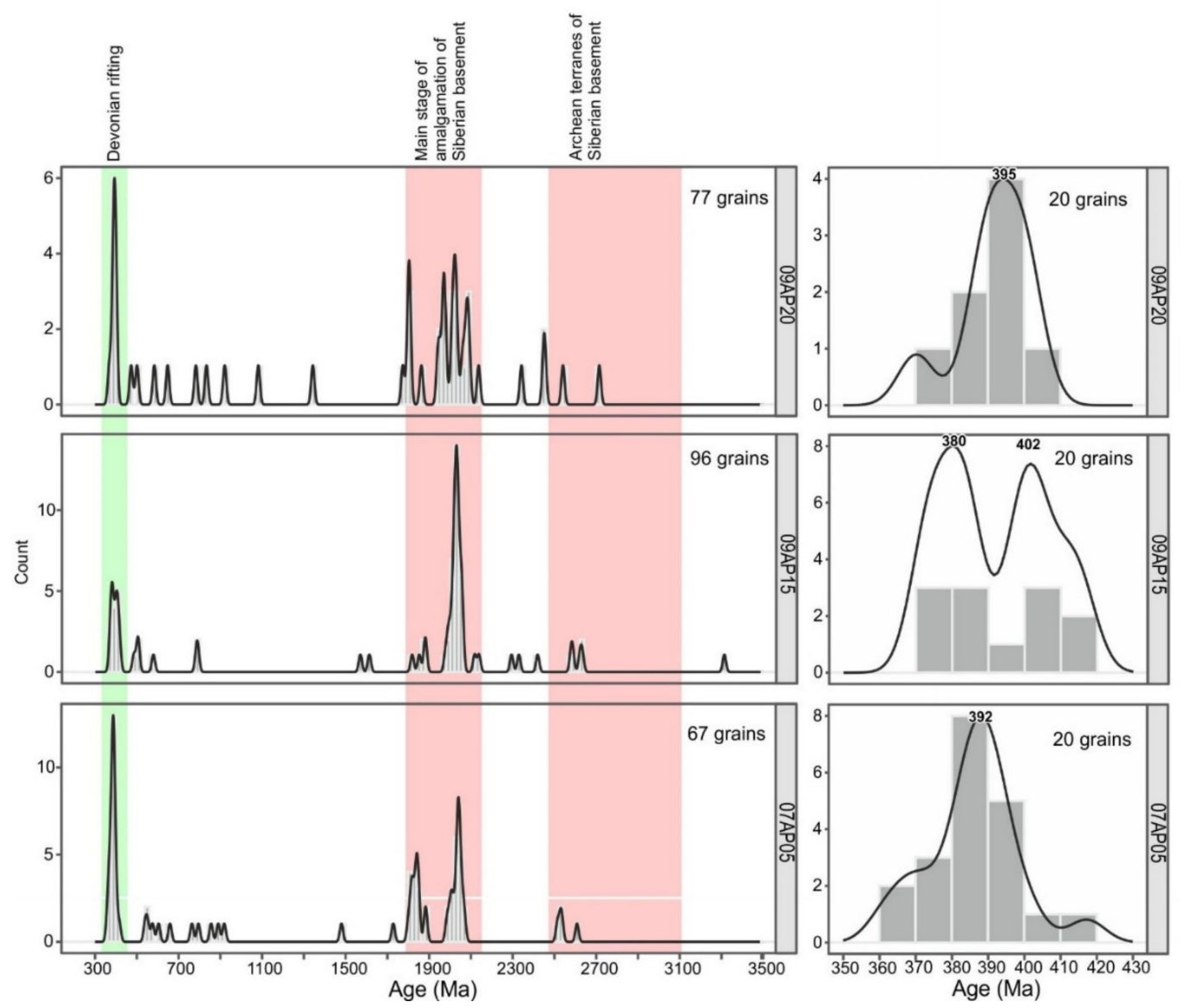

Figure 4. Kernel Density Estimation (KDE) plots show the U-Pb detrital zircon data from Upper Devonian samples analyzed in this paper.

\section{Sample 09AP15 (Famennian)}

Seventy three percent of the dated grains are Precambrian in age (Figure 4). The few Archean grains are grouped at ca. $2500 \mathrm{Ma}$, while Paleoproterozoic grains comprise $63 \%$ and form a major peak at $2000 \mathrm{Ma}$. Three Neoproterozoic zircons do not form any prominent peaks. Paleozoic grains contribute (27\% of the total population) form two peaks at ca. 400 and $380 \mathrm{Ma}$.

\section{Sample 09AP20 (Famennian)}

Sixty five percent of the dated grains are of Precambrian age (Figure 4). Archean grains (5\% of the total population) range in age between 2540 and 2720 Ma. Paleoproterozoic zircons contribute $45 \%$ 
with ages mainly concentrated between 1850 and 2000 Ma. Neoproterozoic grains (12\%) do not form prominent peaks while Paleozoic grains are grouped in a major peak at ca. 395 Ma.

\section{Discussion}

Our integrated provenance analysis is based on both our $\mathrm{U}-\mathrm{Pb}$ detrital zircon age data and our detailed petrographic study. $\mathrm{U}-\mathrm{Pb}$ detrital zircon data provide information on the age of magmatic events in the provenance, while petrographic studies show the composition of rocks in the source region and whether the source region was distal or proximal to the site of sediment deposition. The very immature sandstone composition with a significant proportion of unstable lithic clasts is suggestive of a very proximal source area.

Archean grains are subordinate with ages ranging from 2500 to $2700 \mathrm{Ma}$, correlating with ages of the oldest Archean terranes described from the basement of the Siberian Craton. Detrital zircons within the Devonian sandstones are dominated by Paleoproterozoic grains with ages ranging between 1800 and $2000 \mathrm{Ma}$. These ages can be attributed to the amalgamation of ancient continental terranes to form the Siberian Craton [17,18], with basement rocks of a comparable age described from the Olenek and Ust'-Lena uplifts [19,42]. Moreover, zircons with ages spanning 1800-2000 Ma and 2500-2700 Ma zircons also predominate within Mesoproterozoic-lower Neoproterozoic clastic rocks of northern Siberia [1,3]. Early-Middle Neoproterozoic zircons are subordinate within the Devonian sandstones, although no coeval magmatic event is known from northern Siberia. However, detrital zircons of these ages have also been found within Ediacaran-Cambrian sedimentary strata located in close proximity to the studied Devonian succession [1]. Latest Neoproterozoic-earliest Cambrian zircons could be sourced from coeval volcanics located in close proximity to the studied outcrops [26,27,43].

Devonian detrital zircons are characterized by similar ages to magmatic rocks attributed to the Middle Paleozoic rifting of eastern Siberia $[9,20]$. However, the main rifting events occurred thousands of kilometers to the south of our study region within the Vilyui basin of eastern Siberia [9,11-15]. Devonian zircons within the Devonian sandstones mainly range in age between 400 and $370 \mathrm{Ma}$, with a major peak at $392 \mathrm{Ma}$ (Figure 5).

Several thick Devonian basalt flows have been reported from the Kharaulakh anticlinorium and Lena Delta area [20,27], although there is no evidence of any associated rift basin development. Moreover, the basalts of the study region contain a relatively low number of zircons and are unlikely to represent a major source of detrital zircons. However, silicic volcanics and intrusions are reported in small to moderate proportions in all continental LIPs [44], and felsic trachyandesites of the same age as Late Devonian basalts have also been described from the Vilyui rift basin to the south [14]. Unfortunately, there are no published isotopic ages for these felsic volcanic rocks; however, they are interbedded with sedimentary rocks which have been dated by biostratigraphy as Eifelian-Tournasian $[9,45]$.

40Ar-39Ar age dates of Middle Paleozoic rift volcanics from south-eastern Siberia range between 410 and $345 \mathrm{Ma}[12-15,46,47]$ (Figure 5), comparable to the ages of Devonian detrital zircons from the Devonian sandstones of north-eastern Siberia. Two main pulses of mafic magmatism have been identified within the Vilyui basin, including one at the Frasnian-Famennian boundary, peaking at ca. $375 \mathrm{Ma}$, and another in the latest Devonian, peaking at ca. $365 \mathrm{Ma}[10,11]$. The basalt flows across our study area in north-eastern Siberia occur within the lowermost Frasnian carbonates, with a tentative age assumption of 383-380 Ma. Therefore, as well as yielding low numbers of zircons, the tentative age of these basalt flows does not correlate with the main detrital zircon age peak observed in the Devonian sandstones, providing two lines of evidence that they were not the source of Devonian zircons. We propose that felsic volcanism associated with the Yakutsk-Vilyui LIP may have occurred across a larger part of north-eastern Siberia and may possibly be the provenance for Devonian zircons within the Devonian sandstones of north-eastern Siberia. 


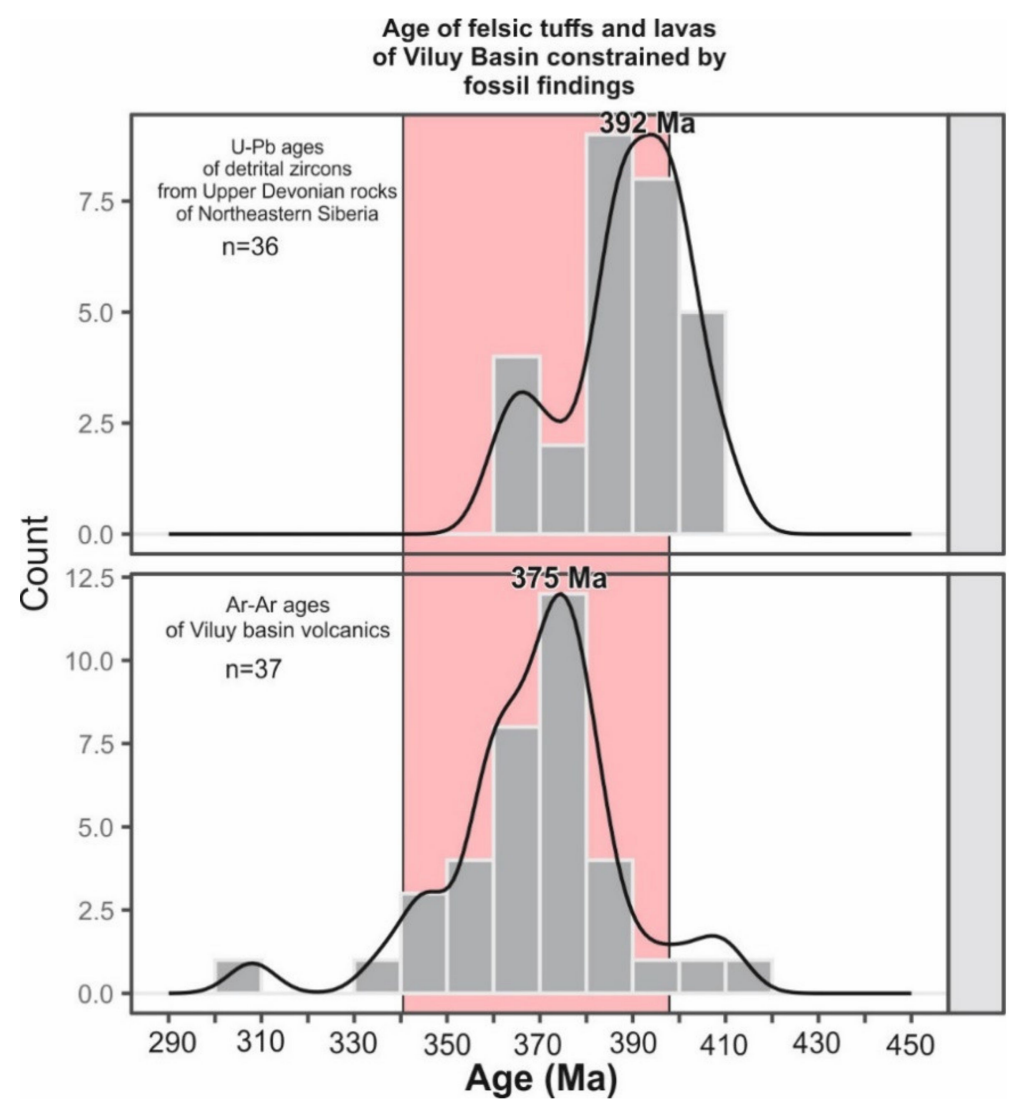

Figure 5. Comparison between Devonian detrital zircon ages from Devonian sandstones of north-eastern Siberia and Ar-Ar ages of volcanic rocks from the Vilyui rift basin (Ar-Ar ages from [12-15,46,47]; rose color bar shows age of felsic tuffs and lavas of Vilyui Basin constrained by fossil findings from $[9,45]$ ).

Our petrographic data suggest that Devonian sandstones have been derived from local uplifts comprising Proterozoic-Devonian rocks and units of Devonian volcanics. Moreover, the abundance of Middle-Late Devonian zircons suggests a potentially larger areal distribution of coeval magmatism across north-eastern Siberia than previously supposed.

We propose that Devonian rift-related magmatism was widespread to the east of our study area, but has subsequently been covered by a thick of Carboniferous-Jurassic clastic succession deposited across the eastern passive margin of Siberia (Figure 6), then deformed into the Verkhoyansk fold-and-thrust belt following Late Jurassic-Cretaceous collision of the Kolyma-Omolon Superterrane. Assuming such a scenario, the age of the main magmatic pulse across north-eastern Siberia is slightly older (ca. $390 \mathrm{Ma}$ ) than the first main magmatic pulse in the Vilyui rift basin across eastern Siberia (ca. 375 Ma; Figure 5). 


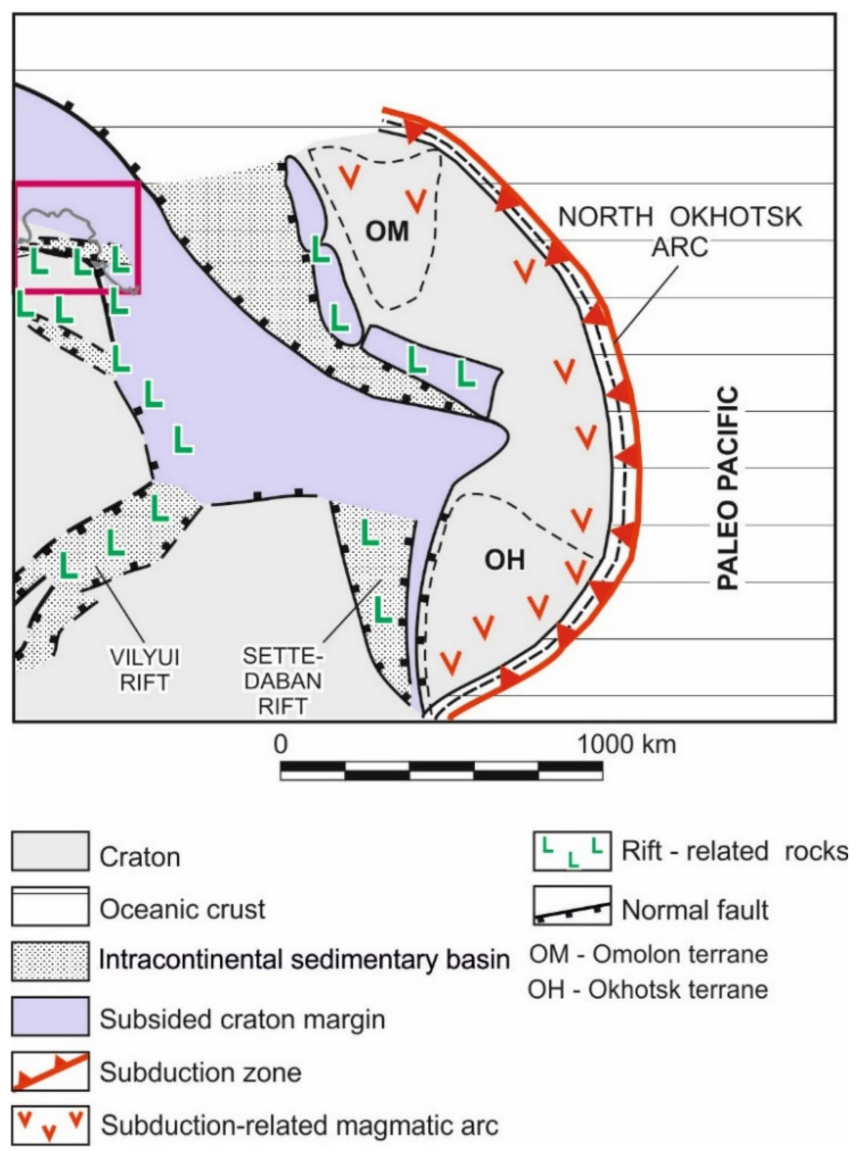

Figure 6. Paleotectonic reconstructions for Late Devonian (modified from [25,29,30,48]).

\section{Conclusions}

Our integrated provenance analysis based on $\mathrm{U}-\mathrm{Pb}$ dating of detrital zircons and sandstone petrography sheds new light on the provenance of Upper Devonian clastic succession deposited across north-eastern Siberia. The immature composition of the sandstones is suggestive of a proximal source region, while the distribution of detrital zircons suggests a source from uplifted blocks comprising Proterozoic-Devonian rocks and units of Devonian volcanics. We propose that Middle-Late Devonian volcanism occurred across a larger part of north-eastern Siberia than previously assumed, and that the major pulse of the Yakutsk-Vilyui LIP occurred in north-eastern Siberia during the Middle Devonian at ca. $390 \mathrm{Ma}$, some 15 million years earlier than within the Vilyui rift basin in eastern Siberia.

Supplementary Materials: The following are available online at http://www.mdpi.com/2075-163X/10/10/874/s1, Figure S1: Concordia diagram for sample 09AP20; Figure S2: Concordia diagram for sample 09AP15; Figure S3: Concordia diagram for sample 07AP05; Table S1: Results of U-Pb dating of detrital zircons.

Author Contributions: V.B.E., writing—original draft preparation; A.V.P., investigation, writing-review and editing; A.K.K., writing-review and editing. All authors have read and agreed to the published version of the manuscript.

Funding: Interpretation of isotopic data and tectonics were supported by the Russian Science Foundation (grant № 20-17-00169). Field work was partly supported by DPMGI SB RAS.

Acknowledgments: We are grateful to James Barnet for correcting the English. Comments by three anonymous reviewers improved the initial manuscript.

Conflicts of Interest: The authors declare no conflict of interest. 


\section{References}

1. Khudoley, A.; Chamberlain, K.; Ershova, V.; Sears, J.; Prokopiev, A.; MacLean, J.; Kazakova, G.; Malyshev, S.; Molchanov, A.; Kullerud, K.; et al. Proterozoic supercontinental restorations: Constraints from provenance studies of Mesoproterozoic to Cambrian clastic rocks, eastern Siberian Craton. Precambrian Res. 2015, 259, 78-94. [CrossRef]

2. Vishnevskaya, I.A.; Letnikova, E.F.; Vetrova, N.I.; Kochnev, B.B.; Dril, S.I. Chemostratigraphy and detrital zircon geochronology of the Neoproterozoic Khorbusuonka Group, Olenek Uplift, Northeastern Siberian platform. Gondwana Res. 2017, 51, 255-271. [CrossRef]

3. Priyatkina, N.; Collins, W.J.; Khudoley, A.; Zastrozhnov, D.; Ershova, V.; Chamberlain, K.; Shatsillo, A.; Proskurnin, V. The Proterozoic evolution of northern Siberian Craton margin: A comparison of U-Pb- $\mathrm{Hf}$ signatures from sedimentary units of the Taimyr orogenic belt and the Siberian platform. Int. Geol. Rev. 2017, 59, 1632-1656. [CrossRef]

4. Ershova, V.B.; Khudoley, A.K.; Prokopiev, A.V. Reconstruction of provenances and carboniferous tectonic events in the North-East Siberian Craton framework according to U-Pb dating of detrital zircons. Geotectonics 2013, 47, 93-100. [CrossRef]

5. Ershova, V.B.; Khudoley, A.K.; Prokopiev, A.V.; Tuchkova, M.I.; Fedorov, P.V.; Kazakova, G.G.; Shishlov, S.B.; O'Sullivan, P. Trans-Siberian Permian rivers: A key to understanding Arctic sedimentary provenance. Tectonophysics 2016, 691, 220-233. [CrossRef]

6. Ershova, V.B.; Prokopiev, A.V.; Khudoley, A.K. Integrated provenance analysis of Carboniferous deposits from Northeastern Siberia: Implication for the late Paleozoic history of the Arctic. J. Asian Earth Sci. 2015, 109, 38-49. [CrossRef]

7. Prokopiev, A.V.; Ershova, V.B.; Miller, E.L.; Khudoley, A.K. Early Carboniferous paleogeography of the northern Verkhoyansk passive margin as derived from $\mathrm{U}-\mathrm{Pb}$ dating of detrital zircons: Role of erosion products of the Central Asian and Taimyr-Severnaya Zemlya fold belts. Russ. Geol. Geophys. 2013, 54, 1195-1204. [CrossRef]

8. Vereshchagin, O.S.; Khudoley, A.K.; Ershova, V.B.; Prokopiev, A.V.; Schneider, G.V. Provenance of Jurassic-Cretaceous siliciclastic rocks from the northern Siberian Craton: An integrated heavy mineral study. J. Geosci. 2018, 63, 199-213. [CrossRef]

9. Gaiduk, V.V. The Middle Paleozoic Vilyui Rift System; YaF SO AN SSSR: Yakutsk, Russia, 1988. (In Russian)

10. Ernst, R.E.; Rodygin, S.A.; Grinev, O.M. Age correlation of Large Igneous Provinces with Devonian biotic crises. Glob. Planet. Chang. 2020, 185, 103097. [CrossRef]

11. Polyansky, O.P.; Prokop'ev, A.V.; Babichev, A.V.; Korobeynikov, S.N.; Reverdatto, V.V. The rift origin of the Vilyui basin (East Siberia), from reconstructions of sedimentation and mechanical mathematical modeling. Russ. Geol. Geophys. 2013, 54, 121-137. [CrossRef]

12. Polyansky, O.P.; Prokopiev, A.V.; Koroleva, O.V.; Tomshin, M.D.; Reverdatto, V.V.; Selyatitsky, A.Y.; Travin, A.V.; Vasiliev, D.A. Temporal correlation between dyke swarms and crustal extension in the middle Palaeozoic Vilyui rift basin, Siberian platform. Lithos 2017, 282-283, 45-64. [CrossRef]

13. Prokopiev, A.V.; Polyansky, O.P.; Koroleva, O.V.; Vasiliev, D.A.; Tomshin, M.D.; Reverdatto, V.V.; Novikova, S.A. The Mid-Paleozoic and Mid-Triassic Pulses of Trap Magmatism in the East of the Siberian Platform: Evidence from the First 40Ar/39Ar Isotope Dating of Dolerite Sills. Dokl. Earth Sci. 2020, 490, 4-7. [CrossRef]

14. Kiselev, A.I.; Ernst, R.E.; Yarmolyuk, V.V.; Egorov, K.N. Radiating rifts and dyke swarms of the middle Paleozoic Yakutsk plume of eastern Siberian craton. J. Asian Earth Sci. 2012, 45, 1-16. [CrossRef]

15. Kiselev, A.I.; Kochnev, B.B.; Yarmolyuk, V.V.; Rogov, V.I.; Egorov, K.N. The early Paleozoic basite magmatism in the northeastern siberian craton. Geodyn. Tectonophys. 2016, 7, 233-250. [CrossRef]

16. Konstantinov, K.M.; Tomshin, M.D.; Ibragimov, S.Z.; Khuzin, M.Z.; Konstantinov, I.K.; Yakovlev, A.A.; Artemova, E.V. Petro- and paleomagnetic studies of basalts of the upper Devonian Appainskaya suite (Western Yakutia). Geodin. Tektonofiz. 2016, 7, 593-623. [CrossRef]

17. Smelov, A.; Timofeev, V. The age of the North Asian Cratonic basement: An overview. Gondwana Res. 2007, 12, 279-288. [CrossRef]

18. Rozen, O.M. The Siberian craton: Tectonic zonation and stages of evolution. Geotectonics 2003, 37, $175-192$. 
19. Prokopiev, A.V.; Smelov, A.P.; Toro, J.; Miller, E.L.; Wooden, J.; Grakhanov, S.A.; Oleinokov, O.B. The Ust'-Lena metamorphic complex (northeast Asia): First U-Pb SHRIMP geochronologic data. Otechestvennaya Geol. 2007, 5, 26-30. (In Russian)

20. Prokopiev, A.V.; Deikunenko, A.V. Deformational structures of fold-and-thrust belts. In Tectonics, Geodynamics and Metallogeny of the Sakha Republic (Yakutia); Parfenov, L.M., Kuzmin, M.I., Eds.; International Academic Publishing Company Nauka/Interperiodica: Moscow, Russia, 2001; pp. 156-198. (In Russian)

21. Grausman, V.V. Geologic section of the 2370 Ust'-Olenek well (depth interval 3605-2700). Tikhookeanskaya Geol. 1995, 14, 137-140. (In Russian)

22. Matukhin, R.G. Devonian and Lower Carboniferous of the Siberian Platform; Nauka Publishing House: Novosibirsk, Russia, 1991. (In Russian)

23. Pogrebitsky, Y.E.; Shanurenko, N.K. Geological Map of Russian Federation and Explanatory Note, Scale 1:1000000 (New Series); S-47-49 (Lake Taimyr); VSEGEI Publishing House: St. Petersburg, Russia, 1998. (In Russian)

24. Ershova, V.B.; Prokopiev, A.V.; Khudoley, A.K. Devonian-Permian sedimentary basins and paleogeography of the Eastern Russian Arctic: An overview. Tectonophysics 2016, 691, 234-255. [CrossRef]

25. Parfenov, L.M. Continental Margins and Island Arcs of Mesozoides of Northeastern Asia; Nauka: Novosibirsk, Russia, 1984. (In Russian)

26. Bowring, S.; Grotzinger, J.; Isachsen, C.; Knoll, A.; Pelechaty, S.; Kolosov, P. Calibrating rates of early Cambrian evolution. Science 1993, 261, 1293-1298. [CrossRef] [PubMed]

27. Prokopiev, A.V.; Khudoley, A.K.; Koroleva, O.V.; Kazakova, G.G.; Lokhov, D.K.; Malyshev, S.V.; Zaitsev, A.I.; Roev, S.P.; Sergeev, S.A.; Berezhnaya, N.G.; et al. The Early Cambrian bimodal magmatism in the northeastern Siberian Craton. Russ. Geol. Geophys. 2016, 57, 155-175. [CrossRef]

28. Prokopiev, A.V.; Khudoley, A.K.; Koroleva, O.V.; Ershova, V.B.; Vasiliev, D.A.; Zaitsev, A.I. New data on Devonian volcanism in the northeast of the Siberian craton. In Geology and Mineral Resources of the North-East of Russia; NEFU Publishing House: Yakutsk, Russia, 2015; pp. 382-384. (In Russian)

29. Parfenov, L.M.; Berzin, N.A.; Khanchuk, A.I.; Badarch, G.; Belichenko, V.G.; Bulgatov, A.N.; Dril', S.I.; Kirillova, G.L.; Kuz'min, M.I.; Nokleberg, W.; et al. Model for the formation of orogenic belts of Central and Northeast Asia. Tikhookeanskaya Geol. 2003, 6, 7-42.

30. Parfenov, L.M.; Badarch, G.; Berzin, N.A.; Khanchuk, A.I.; Kuzmin, M.I.; Nokleberg, W.J.; Prokopiev, A.V.; Ogasawara, M.; Yan, H. Summary of Northeast Asia geodynamics and tectonics. Stephan Mueller Spec. Publ. Ser. 2009, 4, 11-33. [CrossRef]

31. Mezhvilk, A.A. Molasses in the Lena R. delta. Dokl. Earth Sci. 1956, 108, 317-319. (In Russian)

32. Yazikov, A.Y.; Izokh, N.G.; Saraev, S.V.; Bakharev, N.K.; Gonta, T.V.; Sobolev, E.S. New data on the Upper Devonian biostratigraphy and sedimentology of Stolb Island (Lena River delta). Russ. Geol. Geophys. 2013, 54, 780-791. [CrossRef]

33. Menner, V.V.; Sidyachenko, A.I. Upper Devonian of the lower reaches of the river Lena. Dokl. Earth Sci. 1975, 220, 178-181. (In Russian)

34. Gogina, N.I. State Geological Map of the USSR. Scale 1:200,000. Sheet S-52-XXXI, XXXII. Series-Lower Lena. Explanatory Note; Aerogeologia: Moscow, Russia, 1979. (In Russian)

35. Gerdes, A.; Zeh, A. Combined U-Pb and Hf isotope LA-(MC-)ICP-MS analyses of detrital zircons: Comparison with SHRIMP and new constraints for the provenance and age of an Armorican metasediment in Central Germany. Earth Planet. Sci. Lett. 2006, 249, 47-61. [CrossRef]

36. Frei, D.; Gerdes, A. Precise and accurate in situ U-Pb dating of zircon with high sample throughput by automated LA-SF-ICP-MS. Chem. Geol. 2009, 261, 261-270. [CrossRef]

37. Sláma, J.; Košler, J.; Condon, D.J.; Crowley, J.L.; Gerdes, A.; Hanchar, J.M.; Horstwood, M.S.A.; Morris, G.A.; Nasdala, L.; Norberg, N.; et al. Plešovice zircon-A new natural reference material for $\mathrm{U}-\mathrm{Pb}$ and Hf isotopic microanalysis. Chem. Geol. 2008, 249, 1-35. [CrossRef]

38. Nasdala, L.; Hofmeister, W.; Norberg, N.; Martinson, J.M.; Corfu, F.; Dörr, W.; Kamo, S.L.; Kennedy, A.K.; Kronz, A.; Reiners, P.W.; et al. Zircon M257-A Homogeneous Natural Reference Material for the Ion Microprobe U-Pb Analysis of Zircon. Geostand. Geoanalytical Res. 2008, 32, 247-265. [CrossRef]

39. Gehrels, G. Detrital Zircon U-Pb Geochronology: Current Methods and New Opportunities. In Tectonics of Sedimentary Basins; Busby, C., Azor, A., Eds.; John Wiley \& Sons Ltd: Chichester, UK, 2012; pp. 45-62. ISBN 978-1-4443-4716-6. 
40. Kristoffersen, M.; Andersen, T.; Elburg, M.A.; Watkeys, M.K. Detrital zircon in a supercontinental setting: Locally derived and far-transported components in the Ordovician Natal Group, South Africa. J. Geol. Soc. 2016, 173, 203-215. [CrossRef]

41. Pettijohn, F.J.; Potter, P.E.; Siever, R. Sand and Sandstone; Springer: New York, NY, USA, 1987; ISBN 978-0-387-96350-1.

42. Wingate, M.T.D.; Pisarevsky, S.A.; Gladkochub, D.P.; Donskaya, T.V.; Konstantinov, K.M.; Mazukabzov, A.M.; Stanevich, A.M. Geochronology and paleomagnetism of mafic igneous rocks in the Olenek Uplift, northern Siberia: Implications for Mesoproterozoic supercontinents and paleogeography. Precambrian Res. 2009, 170, 256-266. [CrossRef]

43. Pasenko, A.M.; Malyshev, S.V.; DuFrane, S.A.; Shatsillo, A.V. Paleomagnetism and provenance of the lower Cambrian sedimentary rocks of the Udzha Uplift (north of the Siberian platform). Vestn. Spbsu. Earth Sci. 2020, 65. [CrossRef]

44. Ernst, R.E. Large Igneous Provinces; Cambridge University Press: Cambridge, UK, 2014; ISBN 978-1-139-02530-0.

45. Masaitis, V.L.; Bogomolov, E.S.; Lebedev, P.B.; Sergeev, S.A. Middle-Paleozoic volcanic province of the Siberian platform and Sr-Nd systematics of basaltoids. Russ. J. Reg. Geol. Metallog. 2006, 28, 153-157. (In Russian)

46. Courtillot, V.; Kravchinsky, V.A.; Quidelleur, X.; Renne, P.R.; Gladkochub, D.P. Preliminary dating of the Viluy traps (Eastern Siberia): Eruption at the time of Late Devonian extinction events? Earth Planet. Sci. Lett. 2010, 300, 239-245. [CrossRef]

47. Ricci, J.; Quidelleur, X.; Pavlov, V.; Orlov, S.; Shatsillo, A.; Courtillot, V. New 40Ar/39Ar and K-Ar ages of the Viluy traps (Eastern Siberia): Further evidence for a relationship with the Frasnian-Famennian mass extinction. Palaeogeogr. Palaeoclimatol. Palaeoecol. 2013, 386, 531-540. [CrossRef]

48. Prokopiev, A.V.; Ershova, V.B.; Stockli, D.F. Provenance of the Devonian-Carboniferous clastics of the southern part of the Prikolyma terrane (Verkhoyansk-Kolyma orogen) based on $\mathrm{U}-\mathrm{Pb}$ dating of detrital zircons. GFF 2019, 141, 272-278. [CrossRef]

(C) 2020 by the authors. Licensee MDPI, Basel, Switzerland. This article is an open access article distributed under the terms and conditions of the Creative Commons Attribution (CC BY) license (http://creativecommons.org/licenses/by/4.0/). 